\title{
THE CONTROL OF OVULATION IN THE SOW
}

\author{
H. L. BUTTLE* AND J. L. HANCOCK \\ A.R.C. Animal Breeding Research Organization, Edinburgh
}

(Received 17th Fune 1967)

\begin{abstract}
Summary. Sows were injected with HCG 2 days after removal of the litter and were examined at laparotomy for evidence of ovulation at varying intervals from 36 to $44 \mathrm{hr}$ after injection. Ovulation was found to occur about $40 \mathrm{hr}$ after injection. HCG-treated sows shed more eggs than untreated sows. Most treated sows failed to show heat within 6 days of removal of the litter, in contrast with untreated sows.
\end{abstract}

It has been shown (Dziuk \& Baker, 1962; Dziuk, Polge \& Rowson, 1964; Konjuhova, 1966) that the time of ovulation in gilts can be controlled accurately by the intra-muscular injection of human chorionic gonadotrophin (HGG). Radford (1965) has examined the effect on fertility of HCG given to sows 3 days after removal of the litter, but no precise information is available of the effects on ovulation of HGG given to sows, as distinct from gilts. This communication presents information on the time of ovulation and on the occurrence of oestrus in sows injected with HCG within 2 or 3 days of removal of the litter.

The sows used were inbred and outbred animals of various breeds (Large White, Landrace, Wessex and Lacombes) and their crosses, from the Organization pig-breeding units. Sows for treatment were separated from their litters between 50 and 64 days after farrowing. The young were removed between 09.00 hours and noon. Sows treated were injected once intravenously or intra-muscularly with 500 i.u. HGG on the 2 nd or 3 rd day after weaning the litter. The occurrence of oestrus was determined by trial with a boar once or twice daily. The ovaries were examined for evidence of ovulation at autopsy or laparotomy at varying intervals after injection. Ova were recovered by flushing the oviducts at autopsy or at laparotomy using procedures described previously (Hancock \& Hovell, 1962). In what follows, Day 0 is the day of removal of the litter (day of weaning).

In preliminary studies it was found that all of twenty-eight sows injected on the 2nd or 3rd day after weaning had ovulated when examined at autopsy 2 days later; only four of fifteen untreated sows had ovulated within the same period. Accordingly, in subsequent experiments which were designed to specify the time of ovulation after injection, sows were injected on Day 2 and were

* Present address: Division of Agricultural Biochemistry, Department of Biological Chemistry, University of Aberdeen. 
examined at laparotomy 36 to $54 \mathrm{hr}$ later. The time of injection was chosen to exclude as far as possible the occurrence of spontaneous ovulations.

The findings, which are summarized in Table 1, show that ovulation begins in the sow as it does in the gilt, about $40 \mathrm{hr}$ after injection. Ovulation had not begun in any of nine sows examined within $39 \mathrm{hr}$ of injection. Ovulation had begun in two of six sows examined 39 to $40 \mathrm{hr}$ after injection; four of six examined $1 \mathrm{hr}$ later had ovulated and of seventeen sows examined between 41 and $42 \mathrm{hr}$ after injection, sixteen had ovulated.

TABLE 1

THE OCGURRENCE OF OVULATION IN SOWS INJECTED INTRAVENOUSLY WITH 500 i.u. HCG 2 DAYS AFTER REMOVAL OF THE LITTER

\begin{tabular}{c|c|c|c}
\hline $\begin{array}{c}\text { Interval between } \\
\text { injection and } \\
\text { examination }(h r)\end{array}$ & \multicolumn{3}{|c|}{ No. of sows ovulating } \\
\cline { 2 - 4 } & $\begin{array}{c}\text { Ovulation } \\
\text { not begun }\end{array}$ & $\begin{array}{c}\text { Ovulation begun } \\
\text { but incomplete }\end{array}$ & $\begin{array}{c}\text { Ovulation } \\
\text { complete }\end{array}$ \\
\hline 36.01 to 37.00 & 2 & 0 & 0 \\
37.01 to 38.00 & 3 & 0 & 0 \\
38.01 to 39.00 & 4 & 0 & 0 \\
39.01 to 40.00 & 4 & 2 & 0 \\
40.01 to 41.00 & 2 & 4 & 0 \\
41.01 to 42.00 & 1 & 8 & 8 \\
42.01 to 43.00 & 0 & 5 & 5 \\
43.01 to 44.00 & 1 & 3 & 4 \\
\hline
\end{tabular}

Data are available from other experimental material on the numbers of eggs shed by a total of 103 untreated sows and 101 gonadotrophin-treated sows. The mean number of eggs shed by the two groups are 15.7 (untreated) and 17.3 (treated). In an attempt to reduce other sources of variation, comparisons have been made between treated and untreated sows within seven categories of sow which were homogeneous as regards breed, line, parity and degree of inbreeding. In six of the seven categories the untreated sows shed fewer eggs than did the treated sows. The mean ovulation rate for all fiftyeight untreated sows was 15.3 eggs compared with 16.4 eggs for fifty-eight treated sows. The results support the finding above, that HGG increases the number of eggs shed; a similar finding has been recorded by Konjuhova (1966).

Of forty-three sows which were treated with HCG on Day 2 and tested for oestrus until Day 6, only eleven $(25.5 \%)$ showed heat; 158 of $190(83.1 \%)$ untreated contemporary sows showed heat within this period. The findings show that most sows which ovulate precociously as a result of HCG injection fail to show heat and suggest that the treatment inhibits the occurrence of the heat which normally occurs by the 5 th day after weaning.

The findings show that ovulation in the sow can be precisely controlled, as it can in the gilt, by the injection of HCG. Unfortunately the practical value of this finding appears to be limited by the failure of a high proportion of injected animals to show heat. No attempt was made to inseminate treated animals in 
these experiments, but other information (Dziuk \& Polge, 1962, 1965; Radford, 1965) suggests that animals failing to show heat following HCG treatment are unlikely to conceive.

\section{REFERENGES}

DzIUK, P. J. \& Baker, R. D. (1962) Induction and control of ovulation in swine. F. Anim. Sci. 21, 697.

Dziuk, P. J. \& Polge, C. (1962) Fertility in swine after induced ovulation. F. Reprod. Fert. 4, 207.

DzIuk, P. J. \& Polge, C. (1965) Fertility in gilts following induced ovulation. Vet. Rec. 77, 236.

DzIUK, P. J., Polge, C. \& Rowson, L. E. A. (1964) Intra-uterine migration and mixing of embryos in swine following egg transfer. F. Anim. Sci. 23, 37.

Hancock, J. L. \& Hovell, G. J. R. (1962) Egg transfer in the sow. 7. Reprod. Fert. 4, 195.

Konjurova, L. A. (1966) The synchronisation of ovulation in sows by means of chorionic gonadotrophin. Svinovodstvo, Kiev, No. 2, 97-108 (Russ.). Anim. Breed. Abstr. 35, No. 1660.

RAdrord, P. (1965) Synchronisation of ovulation in sows at the first post-weaning oestrus. Vet. Rec. 77, 239. 